\title{
A Field Study for SARS-CoV-2 Evaluation by Two Air Sampling Strategies During Spread in Tehran, Iran
}

\author{
Farah Bokharaei-Salim ${ }^{1}$, Rezvan Zendehdel ${ }^{2}$, Mehrdad Helmi-Kohnehshahro ${ }^{2}$, \\ and Zahra Taherianfar ${ }^{3}$ \\ ${ }^{1}$ Department of Virology, Faculty of Medicine, Iran University of Medical Sciences, Tehran, Iran. \\ ${ }^{2}$ Department of Occupational Health Engineering, School of Public Health and Safety, Shahid Beheshti University \\ of Medical Sciences, Tehran, Iran. \\ ${ }^{3}$ Department of Public Health, School of Public Health and Safety, Shahid Beheshti University of Medical Sciences, \\ Tehran, Iran. \\ *Corresponding Author Email: zendehdel76@yahoo.com \\ Received 13 January 2021, Revised 04 June 2021, Accepted 05 June 2021
}

\begin{abstract}
Outbreak of COVID-19 in different countries is an emergency in global public health recently. According to high spread of the newborn virus, airborne transmission potency of SARS-CoV-2 is possible. Until now, there are contradictory results for air evaluation of newborn virus in the contaminated area. We studied SARS-CoV-2 in the patient room of a hospital by two air sampling strategies. Filtration method and liquid impaction sampling were used simultaneously to assess SARS-CoV-2 in air. Indoor air of seven stations in three hospital wards was evaluated according to glass midget impinger and polytetrafluoroethylene filter. RNA of SARS-CoV-2 was evaluated by real time reverse transcription-PCR. Studied rooms were contaminated by eleven confirmed patients and four suspected cases. Our results show polytetrafluoroethylene filtration and DMEM impaction could not determine the viral concentration in the air samples. The concentration of SARS-CoV-2 in air samples is a trace in the studied stations. In conclusion, sampling strategy is a challenge for newborn virus due to the level of SARS-CoV-2 virus in the air. A trace level of SARS-CoV-2 in the contaminated area could be highlighted higher pathogenicity properties, not disapproval of airborne properties. However, more studies should be performed to characterize new properties of SARS-CoV-2 in the contaminated air.
\end{abstract}

Keyword: COVID-19 outbreak, Air sampling, Filtration, Liquid impaction.

\section{Introduction}

An outbreak of newborn corona virus occurred in Wuhan China in December 2019 [1]. It has been generated acute respiratory disease owing to progressive lung damage. Sever COVID-19 infection resulted in almost $15 \%$ of death in humans [2]. The first confirmed death case from SARS-CoV-2 was reported in February 2020 [3]. By increasing the prevalence of SARS-CoV-2 in different countries, this occurrence is declared as an emergency in global public health [4]. Despite the rapid break-out of disease in the worldwide, characterization of SARS-CoV-2 is still unclear. Such events highlighted the need to develop effective preventing understanding about these new variant viruses.

Inhalation of liquid droplets from infected subjects of SARS-CoV-2 is a cause of human transmission [5-7]. Viral aerosol generation in the patient infected by SARS 
family viruses was confirmed in a cohort study previously [6]. There are contradictory results for air evaluation of newborn virus. Indoor air samples of patient rooms in hospitals were negative in some studies [8,9]. Liu et al., reported SARS-CoV-2 airborne exposure in deposited samples of Wuhan hospitals [10]. WHO has suggested rational use of personal protective equipment as prevention management on $27^{\text {th }}$, February 2020 [7]. Some researchers have criticized this idea due to WHO policies for applying personal protective mask [11]. However, airborne sampling of the SARS-CoV-2 virus has an important role in the managing strategies of the outbreak.

SARS-CoV-2 with spherical shape has a size range between 60-140 nm [12]. National Institute of Occupational Safety and Health (NIOSH) in their guidelines has not been visioned for viral sampling [13]. Overall sampling collection efficiency was related to sampling devices [14]. There are a wide variety of samplers such as impinger, impactor and filters [15-18] for airborne virus sampling. But these samplers have not been suggested as an optimized equipment for indoor air sampling of virus bio-aerosols. Recent studies evaluate the efficiency of filters [19] and impingers [20] for some noninfectious viral sampling in a laboratory scale manner.

Until now, simultaneously two air sampling methods have not been reported for the SARS-CoV-2 evaluation in rooms of the patient with severe respiratory disease. In this study, air samples were investigated in the intensive care unit (ICU) and isolation room (IR) of an Iranian hospital by two sampling strategies. The aim of this study is the assessment of the collecting ability for two sampling devices in SARS-CoV-2 air sampling.
Materials and Methods Study Design

This study was conducted on $25^{\text {th }}$, April 2020 in a hospital in Tehran. This hospital was one of the referral sites in Tehran for the patient with severe acute respiratory difficulty. Tehran as the capital of Iran on March 31, 2020 has the highest level of confirmed cases between different cities in Iran. Air sampling strategies were performed in three wards of the selected hospital by bedridden patients from COVID-19. The number of air samples was the same as another study [9]. Fourteen samples were provided from indoor air in seven stations by two sampling protocols. This study was approved by the Committee on Research Ethics at Shahid Beheshti University of Medical Sciences.

\section{Air Sampling Strategy}

Two commonly collecting methods for viral sampling were used to evaluate SARSCoV-2 virus in a field design. For this aim, the filtration method and sampling approach through liquid impaction was utilized. A personal air sampling pump was applied at the height of $1.5 \mathrm{~m}$ from the floor for each strategy. In liquid impaction, an impinger with a standard nozzle was employed to capture virus aerosols in a collecting liquid. Sampling was performed on the $5 \mathrm{~mL}$ of DMEM media (Dulbecco's Modified Eagl's Medium) containing streptomycin and penicillin. Air samples were prepared by the flow rate of 1.5 $\mathrm{L} / \mathrm{min}$ for $180 \mathrm{~min}$. In the filtration view, polytetrafluoroethylene filters by diameter of $25 \mathrm{~mm}$ and $0.4 \mu \mathrm{m}$ porosity (SKC Inc) were used in the $25 \mathrm{~mm}$ 2-piece cassettes of clear styrene (SKC Inc). Sampling volume of $540 \mathrm{~L}$ was provided in $180 \mathrm{~min}$ by air flowing of 3 L.min ${ }^{-1}$. After the sampling, the top parts of the cassette were removed and the filter was deposited in the sterile tube containing $2 \mathrm{~mL}$ 
of DMEM media. Before sampling, all equipment was typically sterilized by dry heat sterilization operation temperature of $160{ }^{\circ} \mathrm{C}$. All samples in the icebox were transported to a clinical virology laboratory immediately.

\section{SARS-CoV-2 Evaluation}

The RNA of SARS-CoV-2 by triplicate analysis was surveyed based on the real time reverse transcription-PCR. In this way, each sample centrifuged $1.5 \mathrm{~h}$ at $110000 \times \mathrm{g}$ at $4^{\circ} \mathrm{C}$ to suspend the pellet in the media and then passed from the filter by pore size $0.22 \mu \mathrm{m}$ (Merck, Germany). $500 \mu \mathrm{L}$ of media was inoculated in the 96-well microplate containing Vero E6 cells (Pasture Institute, Iran). Each well contains Minimum Essential Medium culture with $4 \%$ fetal calf serum and $1 \%$ glutamine. After 4 days of inoculation, $200 \mu \mathrm{L}$ of media was used for RNA extraction by viral RNA/DNA Mini kit (Vazyme, China). The envelope protein gene of SARS-CoV-2 was employed for virus detection. The sequence of primers and probes were shown in Table 1.

Table 1. Characterize of real time PCR for COVID-2019 evaluation (32).

\begin{tabular}{lc}
\hline Oligonucleotide & \multicolumn{1}{c}{ Sequence } \\
\hline Forward primer & ACAGGTACGTTAATAGTTAATAGCGT \\
Reverse Primer & ATATTGCAGCAGTACGCACACA \\
Probe & ACACTAGCCATCCTTACTGCGCTTCG
\end{tabular}

The reaction was performed by 12.5 $\mu \mathrm{L} 2 \mathrm{X}$ master mix (Invitrogen, USA), $0.5 \mu \mathrm{L}$ specific primers and probe and $2 \mu \mathrm{L}$ nuclease free water. The reaction was implemented at $55^{\circ} \mathrm{C}$ for $10 \mathrm{~min}$, followed by $95^{\circ} \mathrm{C}$ for 3 and then 45 cycles of $95{ }^{\circ} \mathrm{C}$ for $15 \mathrm{~s}, 58^{\circ} \mathrm{C}$ for $30 \mathrm{~s}$ by thermal cycler (Thermo-Fisher Sci., USA). A negative sample was presented by the cycle threshold level higher than 38 .

\section{Results and Discussion}

An overview of four sampling stations in the ICU ward has been presented in Fig. 1. There were eleven COVID-19 confirmed patients in the ICU room. Two cases from these patients have COVID-19 disease by severe sign, four patients have a moderate symptom and others have mild disease severity.

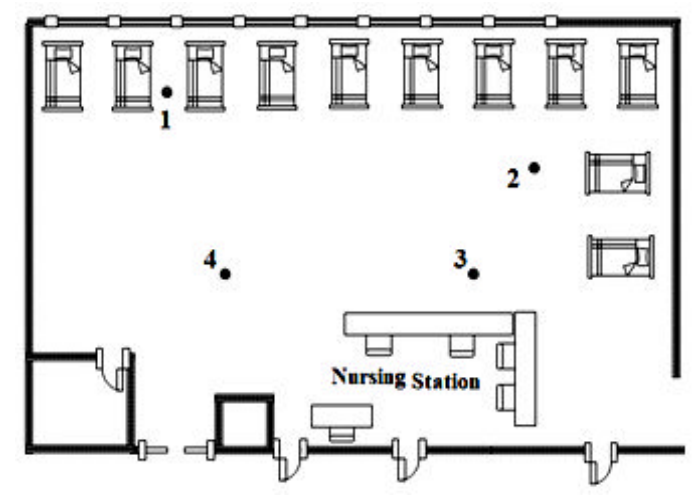

Figure 1. Location of air sampling stations in ICU

Besides the ICU room, two IR rooms were considered for suspected COVID-19 patients. Fig. 2 shows the location of three air samples for the IR wards. All four cases in these rooms have mild sign of respiratory difficulty.
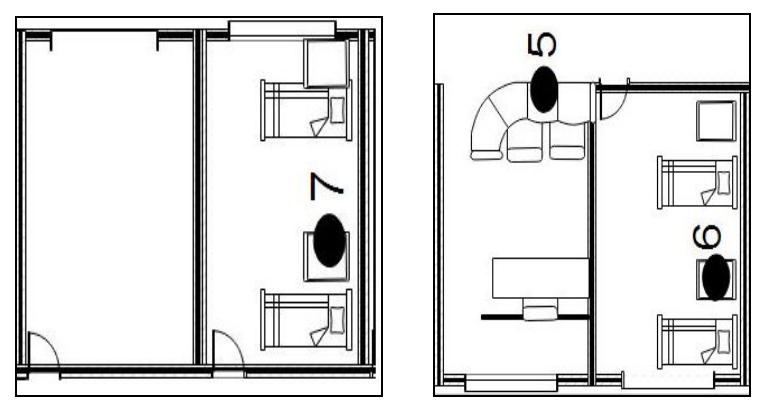

Figure 2. Stations of air samples in isolated room

Table 2 revealed information about patients and healthcare workers in the studied wards for the sampling time. Ventilation of wards was provided by mechanical and natural systems. 
Table 2. Characterization of subjects in the studied wards.

\begin{tabular}{lcccc}
\hline Ward & Patients & $\begin{array}{c}\text { Intubation } \\
\text { treatment }\end{array}$ & $\begin{array}{c}\text { Receiving } \\
\text { oxygen }\end{array}$ & $\begin{array}{c}\text { Health-care } \\
\text { workers }\end{array}$ \\
\hline ICU & 11 & 2 & 11 & 7 \\
IR 2 & 2 & - & 1 & 3 \\
IR 2 & 2 & - & 1 & 2 \\
\hline
\end{tabular}

Results of two sampling strategies presented no SARS-CoV-2 in the airborne of evaluated stations (Table 3 ).

Table 3. Newborn virus evaluation in two sampling strategies.

\begin{tabular}{|c|c|c|c|c|c|}
\hline \multirow[t]{2}{*}{$\begin{array}{c}\text { Ward } \\
\left(\mathbf{m}^{*} \mathbf{m}\right)\end{array}$} & \multirow[t]{2}{*}{ Sample } & \multirow{2}{*}{$\begin{array}{l}\text { Distant } \\
\text { from } \\
\text { patient } \\
\text { (m) }\end{array}$} & \multirow[t]{2}{*}{ Windows } & \multicolumn{2}{|c|}{$\begin{array}{c}\text { SARS-CoV-2 } \\
\text { detection }\end{array}$} \\
\hline & & & & $\begin{array}{c}\text { Liquid } \\
\text { impaction }\end{array}$ & Filtration \\
\hline & 1 & 0.5 & & Negative & Negative \\
\hline \multirow{3}{*}{$\begin{array}{c}\text { ICU } \\
(30 * 10 \\
\quad)\end{array}$} & 2 & 1 & 4 (close) & Negative & Negative \\
\hline & 3 & 5 & & Negative & Negative \\
\hline & 4 & 5 & & Negative & Negative \\
\hline $\begin{array}{l}\text { IR } 2 \\
(4 * 5)\end{array}$ & 5 & 0.5 & 1 (close) & Negative & Negative \\
\hline \multirow{2}{*}{$\begin{array}{l}\text { IR } 2 \\
(4 * 5)\end{array}$} & 6 & 0.5 & 1 (close) & Negative & Negative \\
\hline & 7 & 6 & & Negative & Negative \\
\hline
\end{tabular}

In most viral respiratory infection, airborne exposure to the virus is the main reason for rapid transmission [21, 22]. Whereas there was uncertainty on the transmission route of severe acute respiratory syndrome (SARS) virus. Yu et al., studied 187 confirmed SARS cases from the Hong Kong epidemic by computational modeling [22]. They announced the airborne spread of the virus as a potential route for SARS outbreak [23]. In recent months after COVID-19 prevalence, there was contradictory information about the mode of SARS-CoV-2 transmission.

Recent investigations were shown the newborn virus didn't exist in airborne infected areas. In a recent study, it was reported that no SARS-CoV-2 viruses exist in the ICU airborne of a hospital in Iran [9]. In agreement with this study, Ong et al., found no virus contamination in the airborne exposure of the isolation room for three patients in Singapore [23]. According to these evidence, World Health Organization highlighted that newborn virus transmitted from direct contact, not airborne exposure [24]. Air sampling of SARS-CoV-2 is a difficult because of the ultrafine sizes of the virus. Air sampling device, viral concentration, and air condition affected sampling efficiency [25]. Because of different air sampling methods for recent reports, this study was designed to evaluate newborn virus by two sampling strategies in the same condition for a contaminated hospital.

Studied wards were contaminated by eleven confirmed patients and four suspected cases. Our results show filtration and liquid impaction method could not reveal the viral concentration in air samples. Polytetrafluoroethylene filter [26] and impinger [27] as commercial strategies for viral collecting were suggested in the chamber by experimental design. In the most studies, MS2 non-pathogenic virus nebulized to a chamber by the concentration of $10^{8} \mathrm{PFU} / \mathrm{ml}$ approximately. In these concentrations, MS2 virus was aerosolized in the air of the chamber by the level of $10^{5} \mathrm{no} / \mathrm{m}^{3}$ for sampling implementation [28]. However airborne Influenza virus was quantified with a polytetrafluoroethylene filter at the rate of 3.5 $\mathrm{L} / \mathrm{min}$ [29]. They reported air concentration of Influenza in the patient rooms by minimum of $94 \mathrm{no} / \mathrm{m}^{3}$ and a maximum of $144 \mathrm{no} / \mathrm{m}^{3}$.

On the other hand, SARS-CoV-2 was assessed for $40 \%$ of samples of Liu et al., study [10]. They reported airborne SARSCoV-2 contamination by the concentration between 1-20 no/m [3]. Presented samples show the newborn virus is in the trace level for the contaminated area. In comparison to our study, the positive SARS-CoV-2 samples were prepared by a flow rate of $5 \mathrm{~L} / \mathrm{min}$ through a $25 \mathrm{~mm}$ gelatin filter. In this study 
the volume of $270 \mathrm{~L}$ by the flow rate of 1.5 $\mathrm{L} / \mathrm{min}$ was sampled as the same as another study [9]. It seems that increasing air sampling volume improves the method performance.

The scale of reported SARS-CoV-2 contamination in the air is lower than the Influenza virus. A trace level of airborne SARS-CoV-2 could be directed to higher ability of SARS-CoV-2 than other viruses such as the Influenza virus.

Polytetrafluoroethylene and gelatin filter specified by more than $93 \%$ efficiency in the MS2 viral sampling [30], but evidence based report showed gelatin filters is more efficient for SARS-CoV-2 assessment in the air of real area contamination. Since the gelatin filter dissolved in transparent liquid, sampling efficiency increased for trace viral concentration. SARS-CoV-2 stability in the area surface reduced viral recovery from polytetrafluoroethylene filter. Collection efficiency if impinger for the particles diameter of $50-100 \mathrm{~nm}$ were reported between 10 to $15 \%$ [31]. Our study presented that this efficiency is not enough for the collection of SARS-CoV-2 concertation (1 to $20 \mathrm{no} / \mathrm{m}^{3}$ based otter study).

\section{Conclusion}

In this study, the airborne concentration of newborn virus was studied by two suggested sampling strategies in the field scenario. The results show, although polytetrafluoroethylene filtration and liquid impaction are suitable for the sampling of a high level airborne virus, a trace amount of viral contamination could not be evaluated by these methods. However, the airborne concentration of SARS-CoV-2 is trace. The development of new air sampling strategies required for the evaluation of trace levels of viral concentration in the air.

\section{Acknowledgment}

The researchers also acknowledge the workers of Shohada-E-Tajrish Hospital, Shahid Beheshti University of Medical Sciences.

\section{Declaration of competing financial interests}

This research was financially supported by the School of Public Health and Safety, Shahid Beheshti University of Medical Sciences, Tehran, Iran.

\section{Conflict of Interest}

The authors declare that there is no conflict of interest.

\section{References}

1. C. Sohrabia, Z. Alsafib, M. Khan, A. Kerwanc, A. Al-Jabirc, C. Iosifidisa and C. Aghad, Int. J. Surgery, 76 (2020) 71. https://www.sciencedirect.com/science/a rticle/pii/S1743919120301977

2. W. Guan, Z Ni, Y. Hu, W. Liang, C. Ou and J. He, The New Engl. J. Med., 382 (2020) 1708.

https://www.nejm.org/doi/pdf/10.1056/n ejmoa2002032

3. A. Takian, A. Raoofi and S. Kazempour, The Lancet,10229 (2020) 1035.

https://www.thelancet.com/journals/lanc et/article/PIIS0140-673620306681/fulltext

4. A. F. Mavrogenis, A Quaile and M Scarlat, Int. Orthopaed., 11 (2020), 1. https://www.ncbi.nlm.nih.gov/pmc/articl es/PMC7150532/

5. Y. Liu, Z. Ning, Y. Chen, M. Guo, Y. Liu, N. K. Gali and L. Sun, Nature, 582 (2020) 557.

https://www.nature.com/articles/s41586$\underline{020-2271-3}$ 
6. I. Yu, L. Qiu, L. Tse and T. Wong, Clin. Infect. Dis., 58 (2014) 683. https://pubmed.ncbi.nlm.nih.gov/24319085/

7. World Health Organization Guideline WHO/2019-nCoV/IPC_PPE_use/2020.4 (2020) 1.

apps.who.int > handle > WHO-2019nCov-IPCPPE_use-2020.1-eng.pdf

8. S. Xiang,Y. Tan, Y Chia, TH. Lee, O. Tek, M. Wong and K. Marimuthu, JAMA, 322 (2020) 3227.

https://pubmed.ncbi.nlm.nih.gov/32129805/

9. S. Faridi, S. Niazi, K. Sadeghi, K. Naddafi, K., J. Yavarian, M. Shamsipour, N. Z. Shafiei and K. Sadeghniiat. Sci. Total Environ., 725 (2020) 138401.

https://www.sciencedirect.com/science/a rticle/abs/pii/S0048969720319148

10. Y. Liu, Z. Ning, Y. Chen, M. Guo, Y. Liu, N. Gali, Y. Sun, L. Y. Duan and J. Cai, BioRxiv, (2020).

Doi.10.1101/2020.03. 08.982637. https://europepmc.org/article/ppr/ppr116 $\underline{876}$

11. A. Tajvar, J. Mil. Med., 22 (2020) 1. https://www.google.com/url?sa=t\&rct=j $\& \mathrm{q}=\&$ esrc $=\mathrm{s} \&$ source $=$ web $\& \mathrm{~cd}=\& \mathrm{cad}=\mathrm{rj}$ a\&uact $=8 \& v e d=2$ ahUKEwimno3 ClYTu AhXmShUIHe0PBEYQFjAKegQIHhA C\&url=https\%3A\%2F\%2Fwww.sid.ir\% 2FFileServer\%2FJF\%2F63313990218\& usg=AOvVaw01ag4LZnsPwhBDqiXim CKD

12. T. Hu, M. Frieman and J. Wolfram, Nature Nanotechnol., 15 (2020) 247. https://www.nature.com/articles/s41565020-0674-9

13. NIOSH Manual of Analytical Methods (NMAM), 5th Edition, (2017) 1.

https://www.cdc.gov/niosh/nmam/defaul t.html.

14. L. Riemenschneider, M. Woo, C. Wu, D. Lundgren, J. Wander, J. Lee and H. Li B. Heimbuch, J.Appl. Microbiol., 108 (2010) 315 .

https://pubmed.ncbi.nlm.nih.gov/20002911/
15. M. Pacheco, B. Brito, E. Hartwig, G. R. Smolig, A. Perez, J. Arzt and L. Rodriguez, Transbound. Emerg. Dis., 64 (2017) 564.

https://pubmed.ncbi.nlm.nih.gov/26303975/

16. J. Lednicky and J. Loeb, Res. Treatment, (2013)

Doi.org/10.1155/2013/656825.

https://www.hindawi.com/journals/irt/20 $\underline{13 / 656825 /}$

17. E. Weesendorp, J. M. Wil, L. Stegeman and L. A. Willie, Loeffen, Vet. Microbiol., 127 ( 2008)50.

https://pubmed.ncbi.nlm.nih.gov/178694 $\underline{55 /}$

18. K. Prost, H. Kloeze, S. Mukhi, H. Bozek and Z. Poljak, Transbound. Emerg. Dis., 66 (2019) 1210.

https://www.x-

mol.com/paper/5371113?recommendPap er=1301258380449648640

19. M. Song and H. Su, Microfluidics based impinger for air sampling, The American Society of Mechanical English, (2012) Doi.10. 1115/ICNMM2012-73230 https://asmedigitalcollection.asme.org/IC $\mathrm{NMM} /$ proceedings abstract/ICNMM2012/44793/235/246242

20. W. G. Lindsley, F. Blachere, K. Davis, T. Pearce, M. Fisher, R. Khakoo and S. M. Davis, Clin. Infect. Dis., 50 (2010) 693.

https://pubmed.ncbi.nlm.nih.gov/201000 93/

21. S. L. Brockmeiera, K. M. Lager. Vet. Microbiol., 89 (2002) 267.

https://pubmed.ncbi.nlm.nih.gov/123836 $\underline{36 /}$

22. I. Yu, Y. Li, W. Wong and W. Tam, The New Engl.J. Med., 22 (2004) 1731.

https://www.nejm.org/doi/full/10.1056/n ejmoa032867

23. S. Ong, Y. Tan, Y. Chia, T. H. Lee, O. T. $\mathrm{Ng}, \mathrm{M}$. Wong and $\mathrm{K}$. Marimuthu, Am. Med. Assoc., 323 (2020) 1610. https://jamanetwork.com/journals/jama/f $\underline{\text { ullarticle/2762692 }}$ 
24. World Health Organization Guideline. Modes of transmission of virus causing COVID-19: implications for IPC precaution recommendations (2020) 1. https://www.who.int/newsroom/commentaries/detail/modes-oftransmission-of-virus-causing-covid-19implications-for-ipc-precautionrecommendations

25. L. Gendron, D. Verreault, M. Veillette, S. Moineau and C. Duchaine, Aerosol Sci. Technol., 44 (2010) 893. https://www.tandfonline.com/doi/full/10. $\underline{1080 / 02786826.2010 .501351}$

26. C. Jr, E. Kettleson, M. Lee, B. Ramaswami, L. Angenent and P. Biswas, J. Appl. Microbiol., 99 (2005) 1422.

https://pubmed.ncbi.nlm.nih.gov/16313415/

27. L. Riemenschneider, M. Woo, C. Wu, D. Lundgren, J. Wander J. Lee, H. Li and B. Heimbuc, J. Appl. Microbiol., 108 (2010) 315.

https://pubmed.ncbi.nlm.nih.gov/20002911/
28. N. Leung, J. Zhou, D. Chu, H. Yu, W. Lindsley, D. Beezhold and H. Ye, Plos One, 11 ( 2016) 1.

https://www.ncbi.nlm.nih.gov/pmc/articl es/PMC4743992/

29. Y. Wu, F. Shen and M. Yao, J. Aerosol Sci., 41 (2010) 869.

https://www.sciencedirect.com/science/a rticle/pii/S0021850210001217

30. Z. Wei, R. Rosario land L. Montoya, Atmos. Environ., 44 (2010) 827. https://www.xmol.com/paper/1234600533473193984? $\underline{\mathrm{adv}}$

31. J. Kim, Y. Chung, H. Jo, N. Lee, M. Kim and S. Woo. Osong Public Health Res. Perspect., 11 (2020) 3. https://pubmed.ncbi.nlm.nih.gov/321490 $\underline{36 /}$ 